\title{
Pigmentsejt-eredetú szemfelszíni elváltozások differenciáldiagnózisa és kezelése
}

\author{
Tóth Gábor dr. ${ }^{1}$ - Szalai Eszter dr. ${ }^{2}$ - Csákány Béla dr. ${ }^{1}$ \\ Hécz Réka dr. ${ }^{3}$ - Sándor Gábor László ${ }^{1}$ - Lukáts Olga dr. ${ }^{1}$ \\ Nagy Zoltán Zsolt dr. ${ }^{1}$ - Szentmáry Nóra dr. ${ }^{1,4}$ \\ ${ }^{1}$ Semmelweis Egyetem, Általános Orvostudományi Kar, Szemészeti Klinika, Budapest \\ ${ }^{2}$ Pécsi Tudományegyetem, Általános Orvostudományi Kar, Szemészeti Klinika, Pécs \\ ${ }^{3}$ Semmelweis Egyetem, Általános Orvostudományi Kar, Onkológiai Központ, Budapest \\ ${ }^{4}$ Klinik für Augenheilkunde, Universitätsklinikum des Saarlandes, UKS, Homburg/Saar, Deutschland
}

\begin{abstract}
Célunk a pigmentsejt-eredetű szemfelszíni elváltozások (conjunctivalis naevus, primer szerzett melanosis és conjunctivalis melanoma) összefoglaló ismertetése, különös hangsúlyt fektetve a klinikai megjelenésre, differenciáldiagnosztikára és kezelésre. A naevus a leggyakoribb benignus, pigmentsejt-eredetú conjunctivatumor. A primer szerzett (akvirált) melanosis közép- vagy időskorúakban jelenik meg, a conjunctivalis hám melanocytáinak proliferációja következtében. A conjunctivalis melanoma ritka daganat, a szemfelszíni laphám-neoplasia után a második leggyakoribb szemfelszíni malignus tumor, illetve a chorioidealis melanoma malignumot és a szemfelszíni laphám-neoplasiát követően a harmadik leggyakoribb ocularis malignoma. Rendkívül magas malignitási és áttétképzési potenciálja miatt fontos a korai felismerése és a megfelelő módon való kezelése. A gyakori recidívaképződés miatt kezelésében elengedhetetlen az intra- és posztoperatív adjuváns kezelési módok ismerete és alkalmazása, valamint a rendszeres kontrollvizsgálat.
\end{abstract}

Orv Hetil. 2020; 161(15): 563-574.

Kulcsszavak: naevus, rasszhoz kötött melanosis, primer szerzett melanosis, conjunctivalis melanoma

\section{Differential diagnosis and management of melanocytic lesions of the ocular surface}

Our purpose is to summarize the actual knowledge about melanocytic lesions of the ocular surface (conjunctival nevus, primary acquired melanosis and conjunctival melanoma), especially their clinical appearance, differential diagnosis and treatment. Conjunctival nevus is the most common benign, conjunctival melanocytic lesion. Primary acquired melanosis mainly presents in middle-aged or elderly individuals, characterized by proliferation of melanocytes of the conjunctival epithelial layer. Conjunctival melanoma is a rare tumor, it is the second most common malignant ocular surface tumor after ocular surface squamous neoplasia and the third most common ocular malignancy following choroideal malignant melanoma and ocular surface squamous neoplasia. Early recognition and proper management of conjunctival melanoma is indispensable due to its high malignant and metastatic potential. Due to frequent recurrences, the knowledge and use of intra- and postoperative adjuvant treatment modalities, and regular follow-up are necessary.

Keywords: nevus, racial melanosis, primary acquired melanosis, conjunctival melanoma

Tóth G, Szalai E, Csákány B, Hécz R, Sándor GL, Lukáts O, Nagy ZZs, Szentmáry N. [Differential diagnosis and management of melanocytic lesions of the ocular surface]. Orv Hetil. 2020; 161(15): 563-574.

(Beérkezett: 2019. december 2.; elfogadva: 2020. január 4.) 


\section{Rövidítések}

AJCC $=$ (American Joint Committee on Cancer $)$ Amerikai Rákellenes Vegyes Bizottság; BRAF = v-raf egérszarkóma virális onkogén homológ- $\mathrm{Bl} ; \mathrm{CM}=$ conjunctivalis melanoma; $\mathrm{C}-\mathrm{MIN}=$ conjunctivalis melanocytás intraepithelialis neoplasia $; \mathrm{CPE}=$ conjunctivalis pigmentált elváltozás; $\mathrm{DNS}=$ dezoxiribonukleinsav; IFN $\alpha 2 \mathrm{~b}=$ interferon-alfa-2b; MAPK = mitogénaktivált proteinkináz; MEK = mitogénaktivált proteinkináz kináz; $\mathrm{MMC}=$ mitomicin $\mathrm{C} ; \mathrm{MR}=$ (magnetic resonance $)$ mágneses rezonancia; OSSN $=$ (ocular surface squamous neoplasia $)$ szemfelszíni laphám-neoplasia; PAM = (primary acquired melanosis) primer szerzett melanosis; $\mathrm{PDI}=($ programmed cell death 1) programozott sejthalál-1; PET/CT = (positron emission tomography/computed tomography) pozitronemissziós tomográfia számítógépes tomográfiával; $\mathrm{SNB}=$ sentinelnyirokcsomó-biopszia; TNM = tumor, nodus, metastasis

A benignus conjunctivalis pigmentált elváltozások (CPE-k) közé a conjunctivalis naevus, a rasszhoz kötött melanosis, a potenciálisan praemalignus CPE-k közé a primer szerzett melanosis (PAM) és a malignus elváltozások közé a conjunctivalis melanoma (CM) tartozik [1]. Elkülönítésük nem egyszerü, hiszen számos benignus CPE megjelenése a megtévesztésig hasonlíthat a potenciálisan praemalignus $P A M$ atípiával megjelenő altípusához vagy a malignus CM-hez.

A CM igen ritka, a szemgolyó elvesztésének kockázatával járó és az életet veszélyeztető kórkép, melynek mortalitása 5 év alatt a 30\%-ot, 10 év alatt pedig a 43\%ot is elérheti [2]. A szemfelszíni laphám-neoplasiát (OSSN) követóen a második leggyakrabban előforduló szemfelszíni malignoma, továbbá az uvealis melanoma malignum és az OSSN után a harmadik leggyakoribb ocularis rosszindulatú daganat [3]. Az ocularis tumorok 2-5\%-át és az ocularis melanomák 5-7\%-át teszi ki [4]. Becslések szerint a chorioidealis melanoma előfordulása 20-40×, a bőrmelanoma megjelenése pedig 450-900× gyakoribb a CM-nél. A különböző adjuváns kemo- és radioterápiákkal együtt elvégzett sebészi reszekció ellenére a CM prognózisa kedvezőtlen [1].

\section{Epidemiológia}

A conjunctivalis naevus a leggyakoribb pigmentált kötőhártya-elváltozás. A leggyakrabban fehér bőrü (89\%) emberekben jelenik meg, de előfordul afroamerikaiakban $(6 \%)$, ázsiaiakban (2\%) és hispánokban (1\%) is [5]. A rasszhoz kötött melanosis előfordulása erősen pigmentált bőrü személyeknél nagyon gyakori [6]. A PAM előfordulásáról napjainkig nem közöltek populációalapú adatokat, azonban klasszikusan középkorú, fehér bőrü embereknél jelenik meg, és kétszer gyakoribb a nők körében, mint a férfiak között [7].

A $C M$ incidenciája $0,2-0,8 /$ millió före tehető a kaukázusi népességben és $0,5 /$ millió fơre az Amerikai Egyesült Államokban (USA) [8]. Incidenciája Svédországban az előző évtizedekben emelkedett: 1966 és 2005 között 0,1/millió fơről $0,74 /$ millió fơre a férfiaknál és $0,06 /$ millió föről $0,45 /$ millió főre a nők körében [4].

Shields közleményében (382 fö) a CM-es betegek 94\%-a fehér, 3\%-a fekete bőrü, 2\%-a hispán és 1\%-a ázsiai volt [9]. Fekete bőrü populációban ritkább a CM megjelenése, mint a kaukázusi népcsoportban [10], valamint előfordulása Thaiföldön és Egyiptomban is kifejezetten ritkának bizonyult. Egy, az USA-ban 1973 és 1999 között végzett felmérés szerint a CM incidenciája növekedő trendet mutat a kaukázusi férfiak körében, és incidenciája a bőrmelanomához hasonlóan elsősorban az alacsonyabb szélességi körökhöz közeli területeken emelkedett. A nemi megoszlás tekintetében nincs egyetértés az irodalomban [1].

\section{Etiológia}

A conjunctivalis naevus a leggyakrabban fehér bőrü emberekben jelenik meg, kialakulásában fontos szerepe lehet az ultraibolya sugárzásnak. A rasszhoz kötött melanosis ezzel szemben sötétebb bőrüekben található. A kötőhártya- és a bőrmelanoma incidenciájának növekedése alapján feltételezhető, hogy valamely közös faktornak lehet szerepe a betegség kiváltásában. Ilyen tényező lehet a nap- és az ultraibolya sugárzás [1]. A CM és a bőrmelanoma előfordulási gyakoriságának növekedésében lényeges szerepe lehet az ózonréteg elvékonyodásának és a légköri ultraibolya sugárzás felerôsödésének. A kórkép férfiak körében való gyakoribb előfordulására magyarázat lehet, hogy a férfiak ritkábban védekeznek a napsugárzás ellen (kalap- és napszemüvegviselet), és gyakrabban végeznek szabadtéri tevékenységeket [4].

\section{Hisztopatológia}

\section{Benignus conjunctivalis pigmentált elváltozások}

Ezek közé tartozik a conjunctivalis naevus, a rasszhoz kötött melanosis és az egyéb szisztémás betegségekhez társuló CPE.

\section{Conjunctivalis naevus}

A conjunctivalis naevusok három érettségi szintű és típusú naevussejtból épülnek fel. Az „A” típusú sejtek ovoid alakúak, és apró, dendritikus nyúlványaik vannak, citoplazmájukban melaninszemcsék láthatók [7]. Az „A” típusú sejtek kisebb, lymphocytákra hasonlító „B” típusú sejtekké differenciálódhatnak, melyek a subepithelialis régió mélyebb zónáit foglalják el. Az idősebb betegekben a mélyebb rétegekben megjelennek a fibroblastszerü, „C” típusú sejtek, melyek neuralis eredetűek, és az esetek többségében nem tartalmaznak melanint [11].

\section{A congenitalis naevus}

\section{„Sima” congenitalis naevus}

Változó pigmentáltságú kerek vagy poligonális sejtekből áll, melyek elrendeződése a „sima” szerzett naevuséhoz 

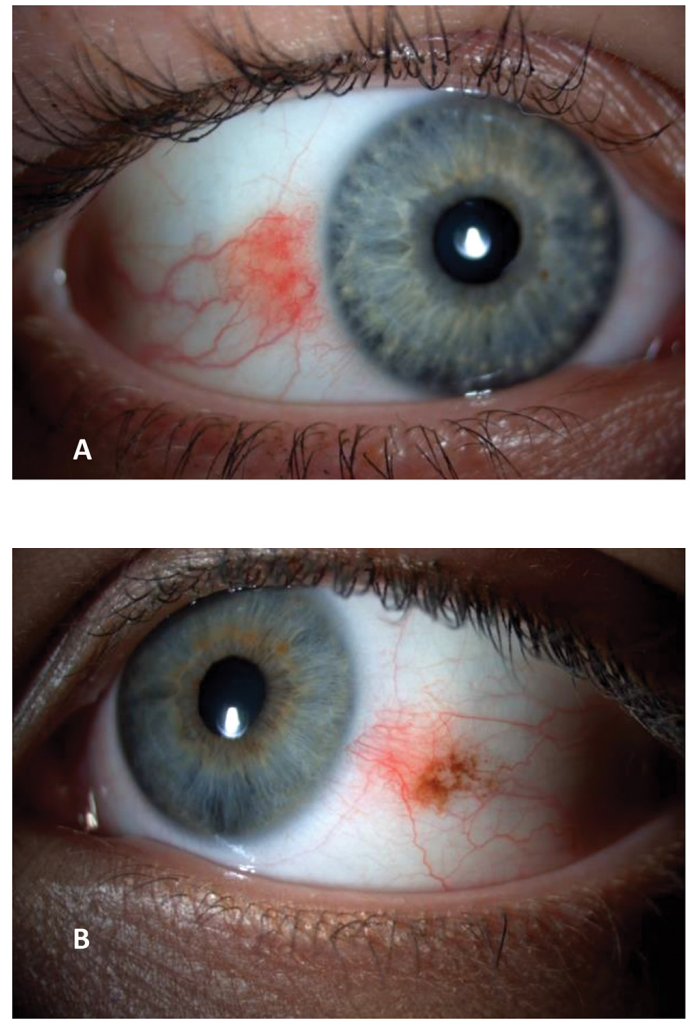

1. ábra

Amelanoticus compound (A) és melanoticus junkcionális (B) naevus conjunctivae klinikai képe, környezetében tágult erekkel

hasonló (lásd alább), azonban a „sima” congenitalis naevusok hipercellulárisabbak. Többnyire számos, nagy junkcionális sejtfészekből állnak [12].

\section{Differenciáldiagnosztika}

Oculodermalis melanosis (Naevus Ota): Inkomplett melanocytamigráció miatt alakul ki, szürkés vagy kékes színû elváltozásként az episclera vagy a sclera szintjében. Malignizálódási hajlamáról nem állnak rendelkezésre adatok [13].

Melanocytoma: Elmosott határú, lapos, koromfekete színú elváltozás. A substantia propria mélyebb rétegeiben vagy az episclerában, sclerában jelenik meg, így nem mozog együtt a kötőhártyával. Malignizálódási hajlama mintegy $1 \%[14]$.
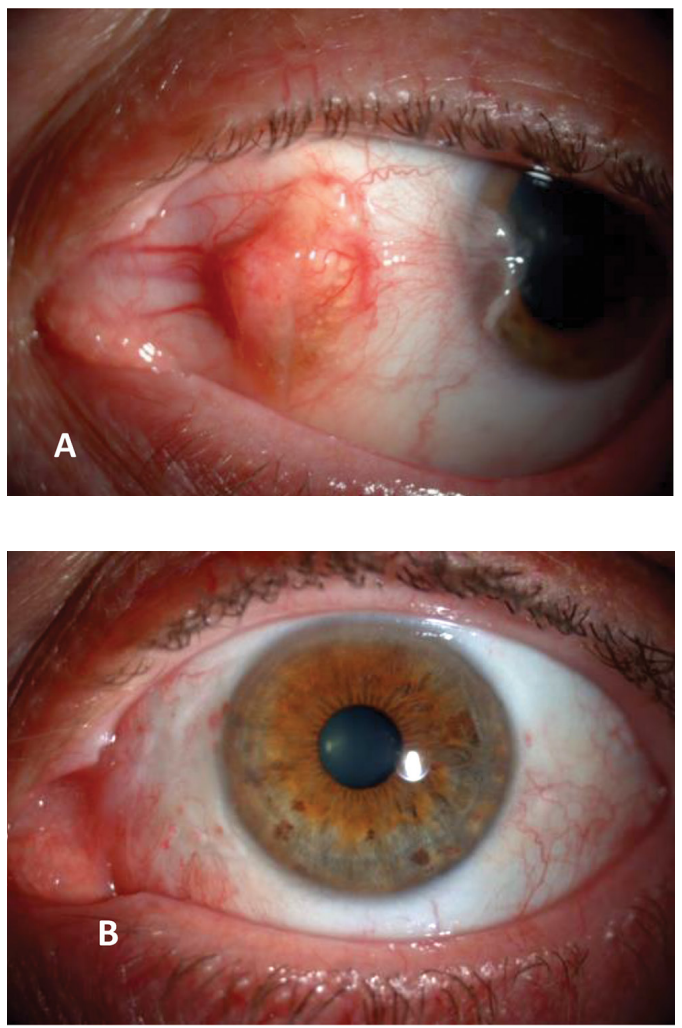

2. ábra

Pterygiummal kombinált subepithelialis naevus conjunctivae klinikai képe mútét előtt (A) és hat héttel mútét után (B)

\section{Szerzett naevusok}

A ,sima” szerzett naevusokat (1-3. ábra) az óket felépítő sejtek és azok lokalizációja alapján 3 szövettani típusra osztjuk (junkcionális, compound és subepithelialis). Ezek nem tekinthetôk egymástól teljesen elkülönülő entitásoknak, inkább a melanocytás naevus érési folyamatának különböző állomásai [15].

a) Junkcionális naevus: A kerek naevussejtek kizárólag az epitheliumban jelennek meg, helyenként sejtfészkeket formálva. Szövettanilag a PAM-tól nehezen különböztethető meg. Elkülönítésében segítségünkre lehet két fontos információ: 1) a junkcionális naevusok előfordulása extrém ritka (kb. 2\%) a kötőhártyanaevusok között; 2) a junkcionális naevusok kizárólag gyermekekben vagy

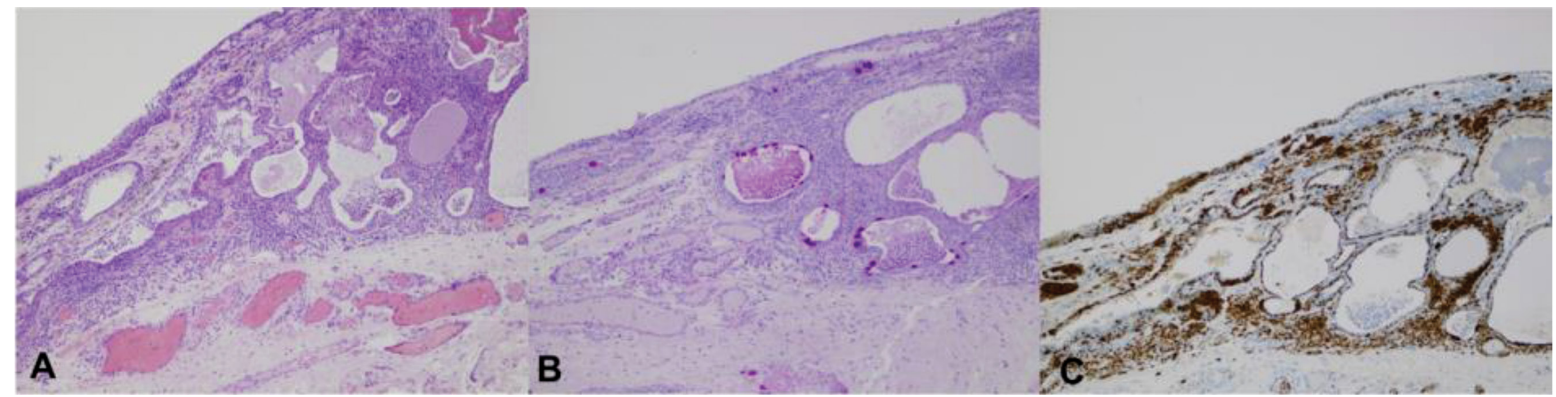

Conjunctivalis naevus. Diffúzan elhelyezkedő és néhol fészkekbe rendeződő subepithelialis naevussejtek, hámeredetú inklúziós cysták, valamint a substantia propriában - pterygiumra jellegzetes - solaris elastosis látható (A, hematoxilin-eozin, nagyítás: 100×). A perjódsav-Schiff (PAS)-festés a hámsejtek

közötti kehelysejteket teszi láthatóvá (B, nagyítás: 100x). A naevussejtek egyforma és diffúz S-100 immunfestődést mutatnak (C, nagyítás: 100x) 

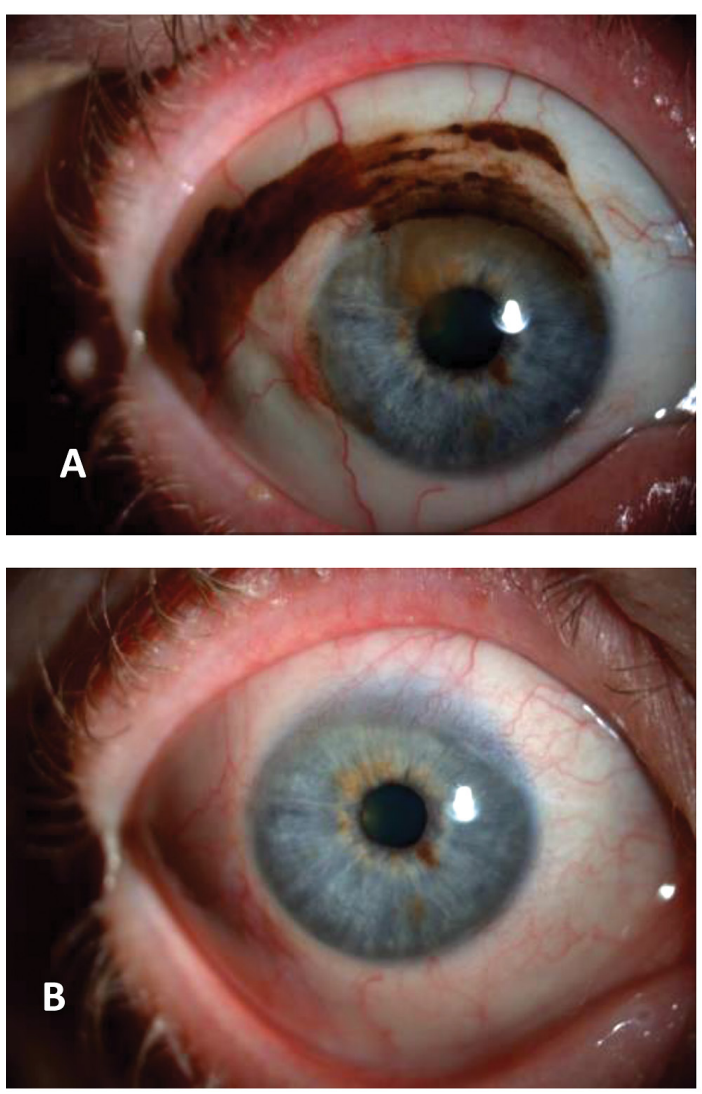

4. ábra

PAM atíiával (melanoma in situ) intraoperatív, lokális adjuváns cryo- és kemoterápiával $(0,01 \%$-os mitomicin C) kiegészített mútét elótt (A) és 2 évvel az után (B)

$\mathrm{PAM}=$ primer szerzett melanosis

fiatal felnőttekben jelennek meg, a PAM pedig csak közép- vagy időskorú emberekben.

b) Compound naevus: A naevussejtek (idővel, az érési folyamat során) lesüllyednek a basalis membrán alá, és az epitheliumon kívül megjelennek a felszínes substantia propriában is. c) Subepithelialis naevus: A naevus (idővel) elveszti intraepithelialis komponensét, és a naevussejtek csak a substanstia propriában lesznek láthatók [5].

Spitz-naevus: Az epitheliumban és a subepitheliumban elhelyezkedő, a felszínre merőleges elhelyezkedésű köteges orsósejtekből áll, de esetenként epitheloid sejteket is tartalmazhat. A subepithelialis részen néhány mitotikus alak is megfigyelhetó, ami a klinikumban is tapasztalt gyors növekedést magyarázza [16].

\section{Rasszhoz kötött melanosis (bőrszínnel asszociált pigmentáció)}

A hámréteg stratum basale rétegének egyenletes hiperpigmentációja látható a szövettani vizsgálatakor [6].

\section{Egyéb szisztémás betegségekhez társuló CPE}

Klinikailag pigmentált vagy nem pigmentált melanocytás elváltozás benyomását keltheti, szövettanilag azonban melanocyták jelenléte nem igazolható [5].

\section{Potenciálisan praemalignus conjunctivalis pigmentált elváltozás}

\section{PAM}

a) PAM atípia nélkül

A conjunctivalis melanocyták proliferációja egyetlen sorban a stratum basale rétegében. Arról, hogy idővel át tud-e alakulni atípiával megjelenó PAM-má, nincsenek ismereteink [17].

\section{b) PAM atípiával}

Sejtatípia és a melanocyták felszínesebb epithelrétegekbe való terjedése (strukturális atípia) jellemzi. Néhány szerző a PAM elnevezés helyett ma már a conjunctivalis melanocytás intraepithelialis neoplasia (C-MIN) kifejezés használatát javasolja (4. és 5. ábra). A conjunctivalis epithelium teljes vastagságának érintettsége esetén beszélünk „melanoma in situ”-ról [18, 19].

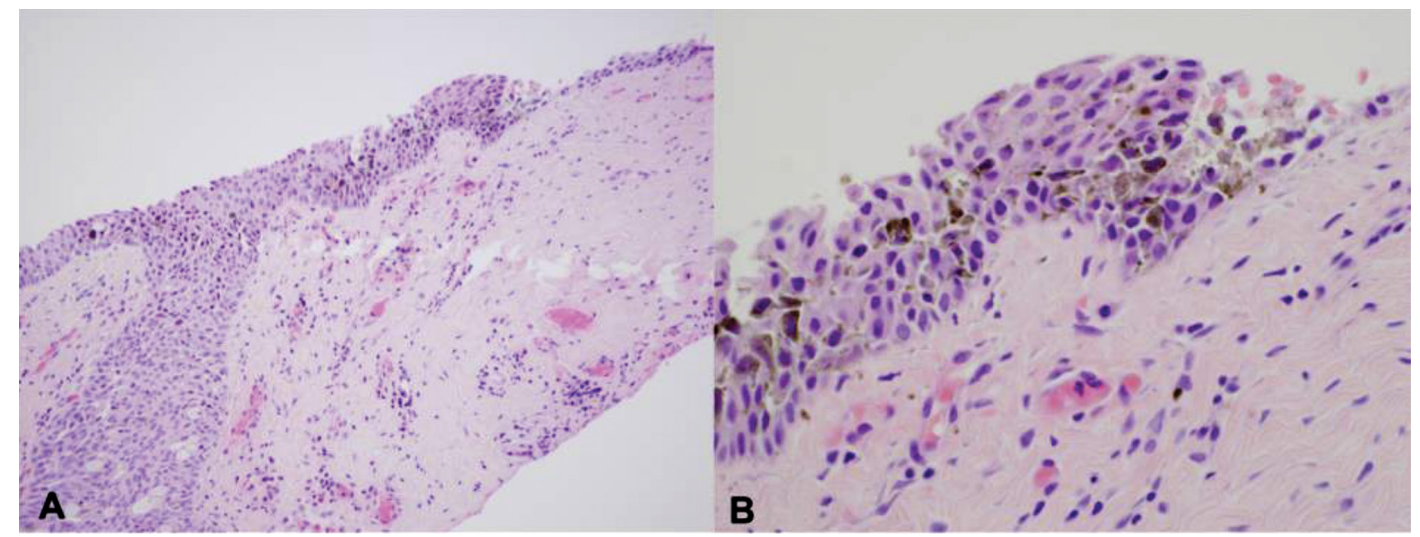
eozin, nagyítás: 100×). A pigmentet tartalmazó sejtek pleomorf, kerek és orsó alakú sejtmaggal, változó mennyiségű citoplazmával rendelkeznek (B, hematoxilin-eozin, nagyítás: $600 \times$ ) 


\section{Malignus conjunctivalis pigmentált elváltozás}

\section{Conjunctivalis melanoma}

A CM-nek (6. és 7. ábra) a conjunctivalis naevustól csupán hisztopatológiai vizsgálat alapján történő elkülönítése sokszor nagy kihívást jelent. Elkülönítése komplex hisztopatológiai szemléletet igényel, a celluláris atípia, a pagetoid terjedés és a sejtérés hiánya a $\mathrm{CM}$ diagnózisát erősíti [7]. A CM szövettani megjelenése változatos, tartalmazhat polyhedralis, orsó-, epitheloid és ballonsejteket, illetve ezen sejtformák keverékét [20].

Az S-100, HMB-45 és Melan-A tumormarkerek többnyire pozitivitást mutatnak az immunhisztokémiai vizsgálatok során, ezért CM gyanúja esetén elvégzésük javasolt, továbbá ajánlott laborvizsgálat során a laktát-dehidrogenáz-szint mérése, melynek emelkedett szintje rosszindulatú daganat jelenlétére utal [21].
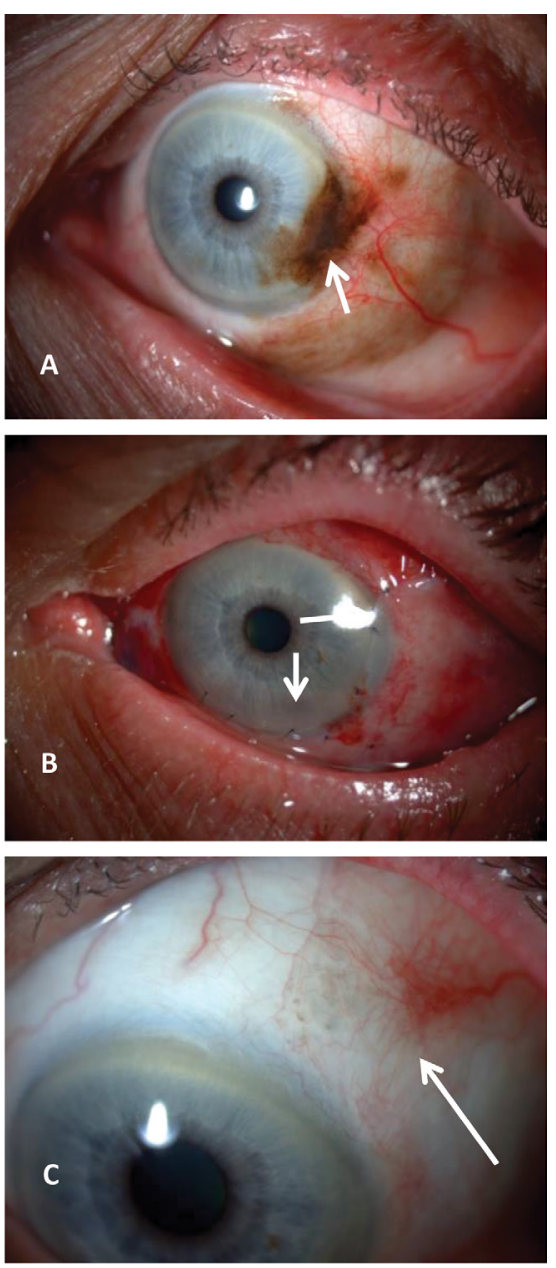

6. ábra

PAM talaján kialakult, a szaruhártyára ráterjedő és a sclerát is usuraló melanoma malignum (nyíl), sentinelérrel (A). Az intraoperatív, lokális adjuváns cryo- és kemoterápiával $(0,01 \%$-os mitomicin C) kiegészített exstirpatiót követően a conjunctivahi ányt amnionmembrán grafttal pótoltuk, melynek varratai jó láthatók (nyilak) (B). 6 hónappal később pigmentált eltérés jelent meg 1 óránál a sclerában, valamint conjunctivalis recidívát észleltünk (nyíl, C)

$\mathrm{PAM}=$ primer szerzett melanosis
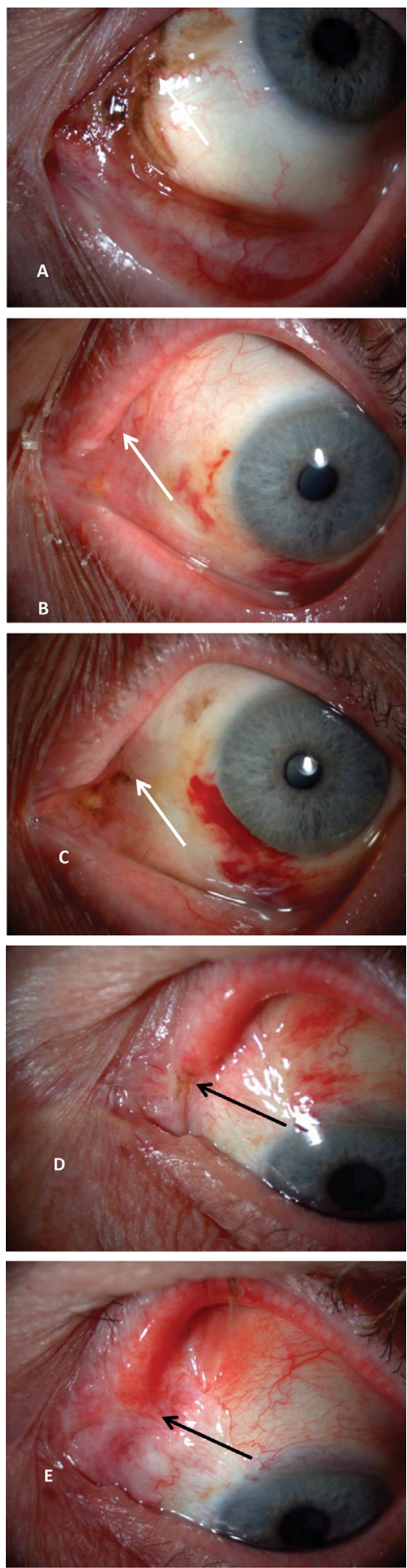

7. ábra $\quad$ PAM atípiával (melanoma in situ) (A, nyíl), melynek szövettani vizsgálata atípiát és magas proliferációs rátát igazolt. 2 hónappal az intraoperatív, lokális adjuváns cryo- és kemoterápiával $(0,01 \%$-os mitomicin C) kombinált sebészi excisio, conjunctivaplasztika és amnionpótlás után a felső tarsalis conjunctiván (B, nyíl), majd 1 hónappal később a bulbaris conjunctiván jelentkezett kiterjedt recidíva (C, nvíl). A recidíva eltávolítását követő szövettani vizsgálat melanoma malignumot igazolt. Az ismételt, kiterjedt intraoperatív, lokális cryo- és adjuváns kemoterápiával $(0,01 \%$-os mitomicin $\mathrm{C})$ kombinált sebészi excisio után 1 hónappal megjelenő recidívát (D) lokálisan napi $4 \times 1$ csepp 1 millió $\mathrm{U} / \mathrm{ml}$ IFN $\alpha 2$ b alkalmazásával kezeltük, melynek köszönhetően 2 hónappal később conjunctivalis pigmentáció nem volt látható $(\mathrm{E})$

PAM $=$ primer szerzett melanosis 


\section{Klinikai jellemzők}

\section{Benignus conjunctivalis pigmentált elváltozások}

\section{Conjunctivalis naevus}

Csoportosítás a megjelenésük ideje szerint:

1. Congenitalis naevus (veleszületett vagy a születést követő 6 hónapban jelenik meg)

„Sima” congenitalis naevus: A legtöbbször sem klinikailag, sem szövettanilag nem lehet elkülöníteni a szerzett compound és subepithelialis naevustól. Gyakran nagyobb területen, diffúzabban jelenik meg, mint a szerzett naevus, valamint együtt jelenik meg az azonos oldali alsó és felső szemhéjak congenitalis naevusával („kissing naevi”). Malignizálódási hajlamáról nem állnak rendelkezésre adatok [5].

2. Szerzett naevus (a legkorábban a születést követő 7. hónapban jelenik meg)

„Sima" szerzett naevus

a) Junkcionális naevus: Lapos, pigmentált elváltozás. Az atípiával járó PAM-tól való klinikai elkülönítésében kizárólag megjelenésének ideje lehet segítségünkre.

b), c) Compound és subepithelialis naevus: A kötőhártya síkjából kiemelkedő elváltozások.

A szerzett naevusok az élet első évtizedében jelennek meg egyoldali, fokális, pigmentált vagy nem pigmentált (1. és 2. ábra) laesio formájában. Pigmentáció esetén színük a világosbarnától az egészen sötét barnáig terjedhet, szélük jól körülhatárolt, 30\%-uk nem pigmentált (amelanoticus). Epithelialis cysták jelenléte a conjunctivalis compound vagy subepithelialis naevus klinikai diagnózisa mellett szólhat.

Kötőhártyanaevusok a leggyakrabban a juxtalimbalis régióban jelennek meg, de esetenként láthatóak a plicán, a carunculán és a szemhéjszéleken is. Amennyiben a kötőhártya palpebralis részén vagy a fornixban helyezkednek el, akkor minden esetben potenciálisan praemalignusnak vagy malignusnak kell tekintenünk ôket [22].

A kötôhártyanaevus szabadon elmozdítható a bulbus felszínén, mert az nem involválja sem a Tenon-kapszulát, sem az episclerát vagy a sclerát (kivételt jelentenek a különösen ritka, tarsalis elhelyezkedésű naevusok, hiszen ott a substantia propria a tarsusszal szorosan összenőtt), és sohasem terjed a cornea állományába (szemben a PAM-mal és a CM-mel). A pigmentált elváltozáshoz húzódó „feeder” erek előfordulási gyakorisága conjunctivanaevusban és CM-ben hasonló [23].

Amennyiben egy közép- vagy időskorú páciensben a kötőhártyanaevus mellett lapos pigmentáció jelenik meg, akkor azt minden esetben potenciálisan PAM-nak kell tekintenünk. Subepithelialis naevusból különösen ritkán alakul ki CM [5].

\section{Spitz-naevus}

Ritkán conjunctivalis, általában nem pigmentált, gyakran erezettséget mutató és gyorsan növekvő elváltozás, mely gyermek- vagy serdülőkorban jelenik meg. A rapid növekedési mód a CM gyanúját is felvetheti [16].

\section{Rasszhoz kötött melanosis}

Sötét bőrpigmentációjú emberekben előforduló, congenitalis, általában kétoldali, aszimmetrikus, esetenként kiemelkedő, bulbaris kötóhártyában (a leggyakrabban az interpalpebralis régióban) megjelenő, barnás árnyalatú, pigmentált elváltozás, mely esetenként a cornea perifériás részére is ráterjed, és a bulbus felszínén szabadon eltolható. A legfontosabb a PAM-tól való elkülönítése, mely sötét bőrú emberekben extrém ritka [24].

\section{Egyéb szisztémás betegségekhez társuló CPE}

Kétoldali, intraepithelialisan megjelenő, jellemzően barnás CPE. Klinikai képe a PAM-ra emlékeztethet [5]. Szisztémás betegségekben jelenhet meg:
a) Addison-kór,
b) Recklinghausen-kór,
c) Peutz-Jeghers-szindróma.

\section{Potenciálisan praemalignus conjunctivalis pigmentált elváltozás}

\section{Primer szerzett melanosis, PAM}

Közép- vagy időskorú fehér bőrü betegekben megjelenő, elmosott szélú, lapos, barnás színú (változó színárnyalatú), mindig egyoldali pigmentált elváltozás, mely esetenként multifokális formában jelentkezik. A pigmentáció érintheti a kötóhártya szöveteinek bármelyik részét és a cornealis epitheliumot is. Az érintett terület kiterjedése stabil maradhat, zsugorodhat vagy idővel akár nőhet, továbbá színárnyalata is változhat [17].

Lényeges megkülönböztetni a PAM atípia nélküli, benignus és atípiával megjelenố, potenciálisan praemalignus variánsát. Az atípia nélküli PAM sohasem, míg a PAM atípiával megjelenő variánsa 46\%-ban alakul át CM-mé. Elkülönítésükre minden esetben citológiai vagy hisztopatológiai vizsgálatot kell végeznünk [18].

A PAM-ból kialakuló CM (6. és 7. ábra) elsô klinikai jele lehet a PAM enyhe, plakkszerú megvastagodása, de a mikroinvázió felismeréséhez hisztopatológiai vizsgálat szükséges [7].

\section{Malignus conjunctivalis pigmentált elváltozás}

\section{Conjunctivalis melanoma}

53-75\%-ban az atípiával megjelenő PAM talaján, 1830\%-ban de novo és 5\%-ban kötőhártyanaevusból alakul ki [4].

A $C M$ általában pigmentált, nodularis, esetenként multifokális, kiemelkedő és éles határú kötőhártya-laesióként jelenik meg középkorú vagy idős, kaukázusi embe- 
rekben (6. ábra). Gyakran láthatunk a tumor irányába húzódó vaskos kötóhártyaereket. Epithelialis cysták jelenléte a conjunctivalis compound vagy a subepithelialis naevus klinikai diagnózisa mellett szól, de nem zárja ki a CM-et. A tumor amelanoticus is lehet [1].

A szemészeti vizsgálat során elengedhetetlen a szemhéjak kifordítása, mert a bulbaris conjunctiván (60\%) és a carunculán (15\%) kívül megjelenhet a tarsalis kötőhártyában $(23 \%)$ és a fornixban $(22 \%)$ is [21]. A palpebralis conjunctivában, a fornixban vagy a carunculán megjelenő pigmentáció mindig növeli a malignitás valószínúségét, itt a kötőhártyanaevus előfordulása extrém ritka. CM-ben limbusközeli elhelyezkedés esetén a szaruhártya is érintett lehet, azonban az infiltráció általában felszínes, és nem töri át a Bowman-lamellát [25]. A CM klinikai félrediagnosztizálási rátája (1. táblázat) 1,4\%-ra [8] tehető. Minden esetben fotódokumentációt kell készítenünk az esetleges progresszió megítélésére.

\section{Stádiumbeosztás}

A CM stádiumbeosztása a TNM-rendszer szerint történik [2]. A T betű a primer tumor méretére és kiterjedésére, az $\mathrm{N}$ betű a regionális nyirokcsomó érintettségére, az $\mathrm{M}$ betû a távoli áttétre vonatkozó információkat jelöli.

A legfontosabb prognosztikai tényezők a nem bulbaris lokalizáció, a korábbi tumorrecidíva, az inkomplett excisio, a nodularis növekedés, a de novo kialakulás és a tumorvastagság. A $2 \mathrm{~mm}$ feletti tumorvastagság és a fornixban, a carunculán, a plica semilunarison vagy a szemhéjszélen lévő lokalizáció kedvezőtlenebb prognózist jelent [26].

A CM a bőrmelanomához hasonlóan a regionális nyirokcsomókba ad először áttétet (12-25\%), szemben a chorioidealis melanoma malignummal, amelyre elsősorban a hematogén távoli áttétképzés jellemző [27].

A betegvizsgálat elengedhetetlen része a regionális submandibularis, parotidealis, cervicalis és praeauricularis nyirokcsomók tapintással, ultrahangkészülékkel és biopsziával történő vizsgálata [28].

Az American Joint Committee on Cancer által kiadott legújabb, 2019-es Cancer Staging Manual for CM [2] szerint a CM-ben az áttétképződés valószínúsége 4,3 évvel (medián) a diagnózist követően 8,5\%, mortalitása pedig 5,3 évvel (medián) a diagnózis megléte után 10,1\%. A kumulatív mortalitási ráta cTl-es stádium esetén 5 évnél 2,5\% és 10 év után $15,2 \%$, cT2-es stádiumban 5 évnél $28,6 \%$ és 10 év után $43,6 \%$, illetve cT3-as stádiumban 5 évnél 31,6\% a diagnózist követően.

Távoli áttétképződés a páciensek 9-25\%-ánál jelenik meg. A leggyakrabban a májba $(45,8 \%)$, a tüdóbe $(37,5 \%)$, az agyba $(12,5 \%)$, a csontokba $(8,3 \%)$ és a hasüregbe $(8,3 \%)$ ad távoli metastatist. Mütéti eltávolítás esetén gyakoriak a mikroszkopikus CM-residuumok, így 5 évvel a mütét után a betegek 26-60\%-ánál, 10 évvel a mütét után pedig 38\%-uknál látható lokális recidíva.

A mortalitási valószínúségek jelentősen függnek a tumor lokalizációjától. A nem bulbaris elhelyezkedésú (T2-es stádiumú) CM-ek igen agresszívek, 10 éves mortalitásuk háromszor nagyobb, mint a Tl-es stádiumú CM-eknek [29].

\section{Uvealis melanoma malignum extraocularis terje- déssel}

Amennyiben a szemfelszínen sötétbarna növedéket látunk, mely a bulbus felszínével együtt mozog, ultrahangvizsgálatot kell végeznünk az extraocularis terjedésű uvealis melanoma malignum kizárására [30].

1. táblázat |A pigmentált szemfelszíni elváltozások differenciáldiagnosztikája

\begin{tabular}{|c|c|c|c|c|}
\hline A laesio típusa & Elhelyezkedés & A megjelenés ideje & Morfológia & Malignizálódási hajlam \\
\hline \multicolumn{5}{|l|}{ Naevus } \\
\hline Junkcionális naevus & \multirow{3}{*}{$\begin{array}{l}\text { Egyoldali; bulbaris } \\
\text { conjunctiva, caruncula, } \\
\text { plica }\end{array}$} & \multirow{3}{*}{ Az első évtized } & Fokális, lapos, éles határú & \multirow{3}{*}{$1 \%$} \\
\hline Compound naevus & & & $\begin{array}{l}\text { Fokális, kiemelkedő, éles } \\
\text { határú }\end{array}$ & \\
\hline Subepithelialis naevus & & & $\begin{array}{l}\text { Fokális, kiemelkedő, éles } \\
\text { határú }\end{array}$ & \\
\hline Melanocytoma & $\begin{array}{l}\text { Egyoldali; substantia } \\
\text { propria vagy episclera }\end{array}$ & Congenitalis & Lapos, elmosott szélü & $1 \%$ \\
\hline Rasszhoz kötött melanosis & $\begin{array}{l}\text { Kétoldali; bulbaris } \\
\text { kötőhártya, interpalpebra- } \\
\text { lis régió; sötét bőrűekben }\end{array}$ & Congenitalis & Lapos, elmosott szélű & Nincs \\
\hline Primer szerzett melanosis & Egyoldali; fehér bőrúekben & Közép- és időskor & $\begin{array}{l}\text { Lapos, elmosott szélü, } \\
\text { esetenként multifokális }\end{array}$ & $\begin{array}{l}\text { PAM atípia nélkül - nincs } \\
\text { PAM atípiával }-46 \%\end{array}$ \\
\hline Conjunctivalis melanoma & Egyoldali; fehér bőrűekben & Közép- és időskor & $\begin{array}{l}\text { Nodularis vagy multifoká- } \\
\text { lis, kiemelkedő, éles határú }\end{array}$ & Malignus \\
\hline
\end{tabular}

$\mathrm{PAM}=$ primer szerzett melanosis 


\section{Kezelés}

\section{Benignus conjunctivalis pigmentált elváltozások}

\section{Conjunctivalis naevus}

A CM-ek 5\%-a alakul ki kötőhártyanaevusból. A naevus eltávolítása többnyire szükségtelen, elegendő az évenkénti utánkövetés [4]. Minden esetben biopsziát és szövettani vizsgálatot kell végeznünk abban az esetben, ha a CPE a fornixban vagy a tarsalis kötőhártyában jelenik meg [1].

\section{Rasszhoz kötött melanosis és szisztémás} betegségekhez társuló CPE

Mivel nem malignizálódnak, kezelésük, eltávolításuk szükségtelen [5].

\section{Potenciálisan praemalignus conjunctivalis pigmentált elváltozás}

\section{PAM atípiával}

Különösen fontos PAM esetén a szemhéjak gondos kifordítása és vizsgálata, hiszen a PAM esetenként multifokális formában jelenik meg. A könnypont érintettsége esetén a könnyelvezető rendszer is érintett lehet. Amenynyiben az elváltozás kicsi, célszerú excisiós biopsziát végezni az egész CPE eltávolításával. Amennyiben a laesio a kötőhártya felületének egynegyedénél nagyobb területet érint, az elváltozás centrumából vagy az esetlegesen vastagabb területekből érdemes biopsziát venni. Amenynyiben cornealis érintettség is látható, először a szaruhártyahámot távolítjuk el, majd a lecsupaszított Bowman-lamellát etanollal dörzsöljük át, így devitalizálva az esetlegesen ott maradó tumorsejteket [25].

Amennyiben a hisztopatológiai vizsgálat a PAM atípia nélküli variánsát mutatja, és pigmentált szövetet hagyunk a szemfelszínen, úgy elegendő a páciens évenkénti ellenőrzése [17]. Amennyiben a szövettan a PAM atípiával megjelenő variánsát mutatja, javasolt a teljes CPE eltávolítása. Nagy kiterjedés esetén a teljes CPE eltávolítását követően cryotherapiát végezhetünk, mely az intraepithelialis melanocyták elpusztítása mellett a substantia propriát épen hagyja [26].

\section{Lokális kemoterápia - mitomicin C (MMC)}

Az MMC a Streptomyces caespitosus által termelt antimetabolit hatású vegyület, amely a DNS-szintézist gátolja, és így a CM recidíva kialakulásának valószínúségét csökkenti, illetve a mútétet követő hegesedést mérsékli [3]. A PAM atípiával járó altípusának MMC-cseppel való kezeléséről több, kisebb esetszámú közlemény is megjelent. 22 eset $45 \%$-ában teljes remissziót, $41 \%$-ában részleges remissziót tudtak elérni, az esetek 14\%-ában alakult ki lokális recidíva [28]. Pe'er szerint a PAM atípiával járó altípusában összesen $2-5$ ciklusban ( 2 hét kezelés +2 hét kezelésmentes időszak) naponta $4 \times 1,0,04 \%$-os MMC- szemcsepp adása javasolt. Csepegtetés közben a páciens a könnytömlöre kifejtett nyomással akadályozhatja meg az MMC könnycsatornába való jutását [31].

\section{Malignus conjunctivalis pigmentált elváltozás}

\section{Conjunctivalis melanoma}

$\mathrm{Az}$ alacsony esetszámok miatt a CM kezelésére nincsenek standardizált szakmai irányelvek. Leglényegesebb része a tumorszövet teljes sebészi eltávolítása adjuváns kezeléssel kombinálva $[1,25]$. Elengedhetetlen a betegek szemészeti onkológiai tapasztalattal rendelkező centrumokban való ellátása [26].

A teljes kivizsgáláshoz hozzátartozik az adjuváns kezeléssel kombinált sebészi eltávolítást követő hisztopatológiai vizsgálat, releváns genetikai (BRAF-V600E mutáció) és laborvizsgálatok elvégzése, tumor staging, a kezelési terv kidolgozása és a szoros utánkövetés [21].

A metastasisok felderítésére teljestest-PET/CT javasolt, vagy lehetőség hiányában koponya- és orbita-MR, mellkasi, hasi és kismedencei CT-vizsgálat. A beteg figyelmét fel kell hívni a rendszeres onkológiai vizsgálatok szükségességére. Az esetleges nasopharynxérintettség és regionális áttétek miatt fül-orr-gégészeti, bőrre terjedés esetén bőrgyógyászati vizsgálat szükséges. Amennyiben áttétet lehet igazolni, onkoteam összehívása szükséges onkológus, radiológus, sugárterápiás, szemész és bőrgyógyász szakorvosok részvételével a lokális és szisztémás kezelések megtervezésére és összehangolására [26].

\section{Lokális kemoterápia - MMC}

Leírásra kerültek eredmények a CM kizárólagosan 0,04\%-os MMC-vel való kezeléséről (7 eset). 43\%-ban alakult ki teljes és 14\%-ban parciális remisszió, 43\%-ban lokális recidíva jelentkezett. Recidíva főként a nodularis típusú CM-nél került leírásra, mivel az MMC feltehetőleg csak a felszínesebb szöveti rétegekben fejti ki hatását. Emiatt napjainkban önmagában az MMC a CM primer kezelésében nem javasolt [28].

\section{Sebészi kimetszés}

A legfontosabb a tumoros szövet minimális közvetlen érintésével a teljes tumorszövet egy ülésben való sebészi eltávolítása, lehetôleg retrobulbaris érzéstelenítésben (a subconjunctivalis érzéstelenítés a tumor szóródását és a kötőhártya szerkezetének megváltozását idézheti elő). A tumorszövet 2-4 mm-es biztonsági szegéllyel való eltávolítása mellett javasolt lamellaris sclerectomiát, illetve amennyiben a tumor a Bowman-lamellát áttöri, superficialis keratectomiát is végeznünk. Lényeges az eltávolított szövetdarabon az irányok megjelölése, illetve a kimetszésnek nem az épben történte esetén a reoperáció elvégzése $[3,25]$.

A szemfelszín rekonstruálásához a tumoros szövet eltávolítását követően új mûszereket kell használnunk a tumorsejtek szóródásának elkerüléséhez. Kiterjedt kötő- 
hártyahiány esetén kötőhártya-plasztikát, illetve kötőhártya pótlása céljából amnionmembránt graftként vagy szájnyálkahártyát használhatunk [32].

Amennyiben a CM mútéti eltávolítását adjuváns kezelés alkalmazása nélkül végezzük, a recidíva kialakulásának valószínûsége épben történt kimetszés esetén is 60-80\%, ezért javasolt a sebészi eltávolításnak egyéb (lásd alább) intra- vagy posztoperatív adjuváns kezeléssel való kombinálása [33].

Amennyiben a szövettani vizsgálat CM-et igazol, javasolt a mưtét során nem eltávolított, épnek látszó (fóleg a tumor környéki) kötőhártyából több pontban további biopsziás mintákat vennünk (feltérképezés), mely segítségünkre lehetnek később a posztoperatív brachytherapiás kezelés megtervezésében [34].

\section{Exenteráció}

Enucleatio végzése CM-ben nem javasolt a megmaradó conjunctivaszövetek miatt.

Csak kiterjedt, $\geq$ T2-es CM esetében merül fel az exenteráció elvégzésének szükségessége, vagy amennyiben a tumoros szövet nem reagál radioterápiára. T3-ban gyakrabban indikált exenteráció végzése, mint T2-es stádiumban (Scholz szerint 26\% vs. 18\%) [28]. Intraocularis vagy szemizom-érintettség és szemüregi áttét esetén bulbusmegtartó terápiás eljárás nem áll rendelkezésünkre, ilyen esetekben exenteráció végzése javasolt [34]. Shields 150 fós mintájában 13\%-ban kellett exenterációt végezni. Ötéves utánkövetés során a betegek $8 \%$-ánál, 10 év után 16\%-ánál és 15 évet követően 32\%-ánál vált szükségessé exenteráció elvégzése [35].

Exenteráció helyett azonban javasolt lehet protonterápiás kezelést végezni, melynek segítségével a besugárzott szemek 69\%-a megtartható a kezelést követő öt évben [29]. Exenteráció elvégzése nem javasolt igazolt metastasisok esetén, vagy ha az érintett szem az egyetlen látó szem [36].

\section{Sentinelnyirokcsomó-biopszia (SNB)}

A tumor stagingben segíthet a regionális submandibularis, praeauricularis, cervicalis és parotidealis nyirokcsomókból való biopszia. Távoli metastasisok megléte esetén az SNB csak 50\%-ban pozitív, és az SNB-pozitív betegek 26\%-ának nincs távoli metastasisa [21]. Az irodalom 61 CM-ben végzett SNB-ről számol be, melyek 16\%-a volt pozitív és mutatott regionális áttétet [37]. SNB elvégzése helyett a regionális nyirokcsomók ultrahangos vizsgálata merülhet fel.

SNB elvégzése javasolt lehet, ha a következő klinikai és hisztopatológiai feltételek közül legalább kettő teljesül: (1) tumorvastagság $>2 \mathrm{~mm}$; (2) nem limbális lokalizáció; szövettani vizsgálaton: (3) ulceratio; (4) >1 mitotikus alak. SNB-pozitivitás esetén onkológiai gondozásba vétel javasolt [37].

\section{Intraoperatív adjuváns kezelések Cryotherapia}

A „double freeze-thaw” cryotherapia egykor a leggyakrabban alkalmazott adjuváns kezelésként volt ismert CM-ben. A más módszerekkel elérhető lényegesen alacsonyabb recidívagyakoriság miatt azonban önmagában, a sebészi eltávolítással való egyidejü használata a legtöbb intézetben napjainkban már csak elvétve fordul elő [3].

A cryotherapia végzése szignifikánsan csökkenti a recidíva kialakulásának valószínűségét a kizárólagos sebészi excisióhoz képest, a regionális és a távoli áttétképződésre azonban nincs hatása. Brouwer $18 \mathrm{CM}$-es beteget kezelt sebészi excisióval és 7 pácienst sebészi eltávolítással és cryotherapiával. 70,2 hónapos utánkövetésnél lokális recidíva kizárólagos sebészi eltávolítást követően a betegek 50\%-ánál, a sebészi eltávolítás cryotherapiával történő kombinálása esetén 14\%-uknál jelentkezett [38].

A lokális cryotherapia mellékhatása lehet atrophia bulbi, szürke hályog, uveitis és ínhártya-beolvadás, melyek miatt több szerző a kötőhártyaszél enyhe megemelését javasolja a cryovéggel, valamint az érintett kötőhártyaterület bulbaris felszín felőli fagyasztását $[3,38]$.

Mivel több tanulmány is kimutatta, hogy a cryotherapia után a recidíva kialakulásának veszélye szignifikánsan nagyobb, mint brachytherapiát követően, ezért egyre több szemészeti onkológiai centrum a CM kezelésében az intraoperatív cryotherapia helyett brachytherapiát vagy cryotherapiát és brachytherapiát együttesen javasol $[28,34,39]$.

\section{Posztoperatív adjuváns kezelések \\ Lokális kemoterápia - mitomicin C (MMC)}

Sebészi excisio után alkalmazott adjuváns, lokális MMCterápiáról 20 dokumentált eset található. Heindl ajánlása szerint egy ciklusban 2 héten át naponta $4 \times 1,0,04 \%$-os MMC-szemcseppet adjunk, 2 hét kezelésmentes időszakkal kiegészítve, 2-5 ciklusban. Betegeinek 30\%-ánál alakult ki lokális recidíva, 5\%-uknál áttét [28]. Mellékhatásként kötőhártya-hyperaemia, keratitis punctata superficialis, szemhéjduzzanat, könnypontelzáródás, cornealis homály (haze), scleralis beolvadás, steril keratolysis, limbálisőssejt-elégtelenség vagy szaruhártya-erózió jelenhet meg [40].

\section{Lokális immunterápia - interferon-alfa-2b (IFNa2b)}

$\mathrm{Az}$ interferonok (IFN) a természetben is előforduló fehérjék, fontos szerepük van az endogén és exogén ártalmakkal szembeni immunvédekezésben. Használatuk elterjedt a bőrrák és az OSSN kezelésében [3].

Herold 1 millió $\mathrm{U} / \mathrm{ml} \mathrm{IFN} \alpha 2 \mathrm{~b}$-szemcseppet adott naponta $5 \times, 6$ héten át, 9 CM-es és atípiás PAM-os betegnek. 7 betegnél teljes remisszió alakult ki [41]. Finger naponta $4 \times 1$, 1 millió $\mathrm{U} / \mathrm{ml}$ IFN $\alpha 2$ b-szemcseppet adott 3 hónapon át 5 betegnek; 4 esetben teljes remiszszió alakult ki [42]. Kikuchi 5 esetról számol be, sebészi eltávolítást követő napi $4 \times 1,1$ millió $\mathrm{U} / \mathrm{ml} \mathrm{IFN} \alpha 2$ b- 
szemcseppel. 4 páciensnél teljes remisszió állt be, 1 esetben hatástalan kezelés miatt exenterációt kellett végezni [43].

Az IFN $\alpha 2$ b-kezelés mellékhatásprofilja enyhébb, mint az MMC-é, hiszen csak enyhe szemirritációt, hyperaemiát vagy keratitis punctata superficialist okozhat a kezelés alatt [3].

\section{Radioterápia}

Irodalmi ajánlás nem áll rendelkezésre arról, hogy mely betegeknél kell preferáltan radioterápiát választani.

\section{Brachytherapia}

A kezelés során az applikátort a tumor közelében rögzítik, az izotóp által kibocsátott béta- és gamma-sugarak károsítják a tumorsejteket. A kezelést a sebészi excisiót és a kötőhártyaseb gyógyulását követően vagy azzal egy időben kezdjük. Legfőbb előnye, hogy hatását a mélyebben fekvő területeken is ki tudja fejteni. A kezelés frakcionálásával csökkenthető a mellékhatások (szemszárazság, szürke hályog, szekunder glaucoma, ínhártya-beolvadás) kialakulásának valószínûsége [3].

A CM brachytherapiás kezelése csak akkor végezhető, ha az applikátor teljes terjedelmében fedi a tumorágyat és a biztonsági szegélyt. A kezelés nem kivitelezhető, ha az elváltozás caruncula- vagy fornixközeli, a tarsalis kötőhártyában fekszik, vagy ha geometriai formája nem illeszkedik az izotóp alakjához [19].

A stroncium-90-tartalmú applikátorok szemfelszíni daganatok kezelésében való alkalmazását alacsony hatékonyságuk (35 hónapos utánkövetés, 46\%-os recidívamentesség) miatt ma már nem javasolják [34, 39, 44].

Kisebb CM-ek besugárzása ( $5 \mathrm{~mm}$-es mélységig) ruténium-106-tartalmú (Ru) applikátorral végezhető, 2 mm-es mélységre 100-130 Gy energiával [34, 39].

Nagyobb kiterjedésű CM-ek kezelésére jód-125-tartalmú applikátor használata alkalmas.

Karim 19, Tl-es stádiumú CM-et kezelt jód125-brachytherapiával, 1,5-3,0 mm mélységben 100 Gy-vel. 43 hónapos átlagos utánkövetésnél távoli metastasis nem alakult ki, 3 (15\%) betegnél recidíva jelent meg. Emellett a betegek 32\%-ánál súlyos szaruhártyafekély alakult ki, ezért a CM kezelésében használata ma már nem javasolt [45].

\section{Protonterápia}

Nagyobb kiterjedésű, multifokális vagy nem bulbaris elhelyezkedésű CM-ek adjuváns radioterápiás kezeléseként a sebészi excisiót követően végezhető. Előnye a brachytherapiával szemben, hogy a besugárzott terület a tumorágyhoz igazítható. Mellékhatásként szemszárazság, másodlagos zöld hályog vagy limbalisőssejt-elégtelenség alakulhat ki [34].

Wuestemeyer 20 multifokális, T1-es vagy T2-es és 2T3-as stádiumú, 80\%-ban CM-recidíva (sebészi excisio után) protonterápiás kezeléséról ír (6 frakcióban 31 Gy teljes dózis). 38,1 hónapos utánkövetésnél 30\%-ban ala- kult ki recidíva, 30\%-ban metastasis, a betegek 20\%-a elhunyt, 10\%-uknál kellett exenterációt végezni [46].

Scholz 89 multifokális vagy $\geq \mathrm{T} 2$-es stádiumú CM sebészi excisiót követően elvégzett protonterápiás kezeléséről ( 2 hét alatt, 8 frakcióban $45 \mathrm{~Gy}$ ) számol be. 4,2 év medián utánkövetési idő során 33\%-ban alakult ki lokális recidíva és $16 \%$-ban regionális vagy távoli áttétképződés. Az ötéves túlélés 71\% volt, exenterációt később 18 betegnél (20\%) kellett végezni [29].

\section{Metastaticus conjunctivalis melanoma}

Metastaticus és irreszekábilis CM-ek terápiájára nincs standardizált kezelés [25].

A BRAF (v-raf egérszarkóma virális onkogén homológ-Bl) onkogén egy szerin-treonin kinázt kódol a mitogénaktivált proteinkináz (MAPK) jelátviteli úton, aktiváló mutációja a CM-ek 29-50\%-ában megfigyelhető. A BRAF-inhibitorokat sikeresen alkalmazzák igazolt BRAF-V600E mutációjú áttétes bőrmelanoma kezelésére. A MAPK jelátviteli út gátlása BRAF-inhibitorokon kívül MEK- (mitogénaktivált proteinkináz kináz) inhibitorokkal vagy a két vegyülettípus kombinációjával is elérhető [47]. További kezelési lehetőség a T-sejteket serkentő és tumorfelismerő hatásukat fokozó programozott sejthalál fehérjét (PDI) gátló vegyületek (pembrolizumab, nivolumab) alkalmazása is [48].

Pinto Torres egy igazolt BRAF-V600E mutációjú áttétes CM-es betegben ért el komplett remissziót 1 hónapon át alkalmazott, napi $2 \times 960 \mathrm{mg}$, intravénás vemurafenib adásával [49].

Dagi Glass igazolt BRAF mutációjú, irreszekábilis, regionális áttétet adó CM-nél ért el szinte teljes rezolúciót sebészi excisiót és nyaki dissectiót követően alkalmazott, a jelentkező mellékhatások miatt (hányás, szédülés, BRAF-inhibitor elleni rezisztencia) többször is újragondolt, kombináltan adott intravénás BRAF- (dabrafenib, vemurafenib), MEK- (trametinib) és PDI - (pembrolizumab) inhibitorokkal [50].

Pinto Torres BRAF-mutáció nélküli, regionális nyirokcsomókban jelentkező áttétes CM-es beteget kezelt 3 hetenként intravénásan adott $2 \mathrm{mg} /$ testtömegkilogramm (ttkg) pembrolizumabbal, akinél 3 ciklust követően teljes remissziót ért el az áttétek vonatkozásában. Sagiv 4, áttétes CM-es beteg esetében ért el teljes rezolúciót 2 hetenként, 3 hónapon át adott $3 \mathrm{mg} / \mathrm{ttkg}$ intravénás nivolumabkezelést követően; a betegek 36 hónap utánkövetés alatt recidívamentesek voltak [48].

\section{Conjunctivalis melanoma utánkövetése}

Az első évben negyedévenkénti, a 2-5. évben félévenkénti, majd az utolsó kezelést követő ötödik év letelte után évenkénti kontrollvizsgálat javasolt. Külön figyelmet kell szentelnünk a szemhéjak gondos kifordítására és az amelanoticus szövetnövedékekre, mert esetenként a melanoticus CM recidívája amelanoticus is lehet. A staging vizsgálatok elvégzését az esseni szemészeti onkológiai centrum az első öt évben félévenként, majd azt köve- 
tően évenként javasolja. Ilyenkor javasolt fül-orr-gégészeti (a regionális nyirokcsomók és a nasopharynx vizsgálata miatt), bőrgyógyászati és képalkotó (optimálisan $\mathrm{PET} / \mathrm{CT})$ vizsgálat elvégzése is $[26,28,34]$.

\section{Következtetések}

A conjunctivalis naevus, a rasszhoz kötött melanosis, a primer szerzett melanosis és a conjunctivalis melanoma elkülönítésében segíthet megjelenésük helye és ideje, a conjunctivacitológia, -biopszia és a szövettani vizsgálat. Különös odafigyelést igényel potenciális malignizálódási hajlama miatt a PAM atípiával megjelenő altípusa. A CM esetében klinikai és betegbiztonsági szempontokból ajánlott kezelési mód az intraoperatív cryo- és mitomicin-C-terápiával kiegészített sebészi excisiónak posztoperatív lokális kemoterápiával vagy brachytherapiával való kombinálása. Különösen fontos még a pácienseknek szemészeti onkológiában jártas centrumokban való szisztematikus kivizsgálása, a lényegi döntések meghozatalához a társszakmák bevonása és a páciensek élethoszszig való évenkénti szemészeti utánkövetése, az esetleges CM-recidívák és -áttétek időben történő felismerése céljából.

Anyagi támogatás: Készült „Az orvos-, egészségtudományi- és gyógyszerészképzés tudományos múhelyeinek fejlesztése" címü projekt támogatásával (azonosítószám: EFOP-3.6.3-VEKOP-16-2017-00009; Dr. Tóth Gábor). A támogatónak nem volt szerepe a kézirat megtervezésében vagy megírásában.

Szerzői munkamegosztás: T. G., Sz. E., Cs. B., H. R., S. G. L., N. Z. Zs., Sz. N.: Irodalomgyüjtés. T. G., Sz. E., Cs. B., H. R., L. O., N. Z. Zs., Sz. N.: A kézirat megszövegezése és javítása. A cikk végleges változatát valamennyi szerző elolvasta és jóváhagyta.

Érdekeltségek: A szerzőknek nincsenek érdekeltségeik.

\section{Köszönetnyilvánítás}

Köszönjük $d r$. Tóth Jeannette segítségét (Semmelweis Egyetem, II. Sz. Patológiai Intézet) a szövettani felvételek elkészítésében.

\section{Irodalom}

[1] Seregard S. Conjunctival melanoma. Surv Ophthalmol. 1998; 42: 321-350.

[2] Jain P, Finger PT, Damato B, et al. Multicenter, international assessment of the eighth edition of the American Joint Committee on Cancer Cancer Staging Manual for conjunctival melanoma. JAMA Ophthalmol. 2019; 137: 905-911.

[3] Tóth G, Sándor GL, Gyenes A, et al. Ocular surface squamous neoplasia. [Szemfelszíni laphám-neoplasia.] Orv Hetil. 2017; 158: 2011-2022. [Hungarian]
[4] Kaštelan S, Gverovi Antunica A, Beketi Oreškovi L, et al. Conjunctival melanoma - epidemiological trends and features. Pathol Oncol Res. 2018; 24: 787-796.

[5] Folberg R, Jakobiec FA, Bernardino VB, et al. Benign conjunctival melanocytic lesions. Clinicopathologic features. Ophthalmology 1989; 96: 436-461.

[6] Jakobiec FA. The ultrastructure of conjunctival melanocytic tumors. Trans Am Ophthalmol Soc. 1984; 82: 599-752.

[7] Jakobiec FA, Folberg R, Iwamoto T. Clinicopathologic characteristics of premalignant and malignant melanocytic lesions of the conjunctiva. Ophthalmology 1989; 96: 147-166.

[8] Yu GP, Hu DN, McCormick S, et al. Conjunctival melanoma: is it increasing in the United States? Am J Ophthalmol. 2003; 135 : 800-806.

[9] Shields CL, Markowitz JS, Belinsky I, et al. Conjunctival melanoma: outcomes based on tumor origin in 382 consecutive cases. Ophthalmology 2011; 118: 389-395.e2.

[10] Tóth-Molnár E, Oláh J, Dobozy A, et al. Ocular pigmented findings in patients with dysplastic naevus syndrome. Melanoma Res. 2004; 14: 43-47.

[11] Gilde K. Naevus pigmentosus and melanoma. [A naevus pigmentosus és a melanoma.] Magy Onkol. 2003; 47: 19-26. [Hungarian]

[12] Tóth-Molnár E, Vizvári E, Skribek Á, et al. Giant conjunctival nevus in a 12-year-old child. Case Rep Ophthalmol Med. 2017; 2017: 8414352.

[13] Liesegang TJ. Pigmented conjunctival and scleral lesions. Mayo Clin Proc. 1994; 69: 151-161.

[14] Kurli M, Finger PT. Melanocytic conjunctival tumors. Ophthalmol Clin North Am. 2005; 18: 15-24.

[15] Vizvári E, Skribek Á, Polgár N, et al. Conjunctival melanocytic naevus: diagnostic value of anterior segment optical coherence tomography and ultrasound biomicroscopy. PLoS ONE 2018; 13: e0192908.

[16] Wachtel JG, Caplan CW, Makley TA Jr. Juvenile melanoma (mixed spindle cell and epithelioid cell nevus) of the conjunctiva. Surv Ophthalmol. 1967; 12: 12-16.

[17] Alzahrani YA, Kumar S, Abdul Aziz H, et al. Primary acquired melanosis: clinical, histopathologic and optical coherence tomographic correlation. Ocul Oncol Pathol. 2016; 2: 123-127.

[18] Shields CL, Shields JA. Conjunctival primary acquired melanosis and melanoma: tales, fairy tales, and facts. Ophthalmic Plast Reconstr Surg. 2009; 25: 167-172.

[19] Lim LA, Madigan MC, Conway RM. Conjunctival melanoma: a review of conceptual and treatment advances. Clin Ophthalmol. 2013; 6: 521-531.

[20] Orosz Z. Pitfalls in the diagnosis of malignant melanoma. [A melanoma malignum patológiai diagnózisának buktatói.] Magy Onkol. 2003; 47: 27-39. [Hungarian]

[21] Berta-Antalics AI, Kruse FE, Holbach L. Pathology and prognostic factors of conjunctival melanoma. [Pathologie und Prognosefaktoren konjunktivaler Melanome.] Ophthalmologe 2015; 112: 892-898. [German]

[22] Shields CL, Demirci H, Karatza E, et al. Clinical survey of 1643 melanocytic and nonmelanocytic conjunctival tumors. Ophthalmology 2004; 111: 1747-1754.

[23] Shields CL, Shields JA. Tumors of the conjunctiva and cornea. Indian J Ophthalmol. 2019; 67: 1930-1948.

[24] Tóth-Molnár E. Primary melanocytic lesions of the conjunctiva. [A conjunctiva primer melanociter elváltozásai.] Szemészet 2015; 152: 102-111. [Hungarian]

[25] Vora GK, Demirci H, Marr B, et al. Advances in the management of conjunctival melanoma. Surv Ophthalmol. 2017; 62: 26-42.

[26] Glossmann JP, Skoetz N, Starbatty B, et al. Conjunctival melanoma: standard operating procedures in diagnosis, treatment and follow-up care. [Konjunktivales Melanom: Standardisiertes Vorgehen in Diagnostik, Therapie und Nachsorge.] Ophthalmologe 2018; 115: 489-498. [German] 
[27] Shildkrot Y, Wilson MW. Conjunctival melanoma: pitfalls and dilemmas in management. Curr Opin Ophthalmol. 2010; 21 : 380-386.

[28] Heindl LM, Koch KR, Schlaak M, et al. Adjuvant therapy and interdisciplinary follow-up care of conjunctival melanoma. [Adjuvante Therapie und interdisziplinäre Nachsorge des Bindehautmelanoms.] Ophthalmologe 2015; 112: 907-911. [German]

[29] Scholz SL, Hérault J, Stang A, et al. Proton radiotherapy in advanced malignant melanoma of the conjunctiva. Graefes Arch Clin Exp Ophthalmol. 2019; 257: 1309-1318.

[30] Coupland SE, Campbell I, Damato B. Routes of extraocular extension of uveal melanoma: risk factors and influence on survival probability. Ophthalmology 2008; 115: 1778-1785.

[31] Pe'er J, Frucht-Pery J. The treatment of primary acquired melanosis (PAM) with atypia by topical mitomycin C. Am J Ophthalmol. 2005; 139: 229-234.

[32] Módis L, Tóth E, Berta A. Surgical treatment of ocular surface diseases. [A szemfelszín betegségeinek sebészi kezelése.] Orv Hetil. 2009; 150: 1599-1606. [Hungarian]

[33] Damato B, Coupland SE. Management of conjunctival melanoma. Expert Rev Anticancer Ther. 2009; 9: 1227-1239.

[34] Westekemper H, Meller D, Darawsha R, et al. Operative therapy and irradiation of conjunctival melanoma. [Operative Therapie und Bestrahlung konjunktivaler Melanome.] Ophthalmologe 2015; 112: 899-906. [German]

[35] Shields CL, Shields JA, Gündüz K, et al. Conjunctival melanoma: risk factors for recurrence, exenteration, metastasis, and death in 150 consecutive patients. Arch Ophthalmol. 2000; 118: 1497-1507.

[36] Tóth-Molnár E, Hammer H, Tiszlavicz L, et al. Conjunctival malignant melanoma in high grade lymphocytic lymphoma patient - case report. [Kifejezett malignitású non-Hodgkin T-sejtes lymphomás betegben kialakult melanoma malignum conjunctivae - esetleírás.] Szemészet 2000; 137: 209-211. [Hungarian]

[37] Aziz HA, Gastman BR, Singh AD. Management of conjunctival melanoma: critical assessment of sentinel lymph node biopsy. Ocul Oncol Pathol. 2015; 1: 266-273.

[38] Brouwer NJ, Marinkovic M, van Duinen SG, et al. Treatment of conjunctival melanoma in a Dutch referral centre. Br J Ophthalmol. 2018; 102: 1277-1282.

[39] Missotten GS, Keijser S, De Keizer RJ, et al. Conjunctival melanoma in the Netherlands: a nationwide study. Invest Ophthalmol Vis Sci. 2005; 46: 75-82.
[40] Ditta LC, Shildkrot Y, Wilson MW. Outcomes in 15 patients with conjunctival melanoma treated with adjuvant topical mitomycin C: complications and recurrences. Ophthalmology 2011; 118: 1754-1759.

[41] Herold TR, Hintschich C. Interferon $\alpha$ for the treatment of melanocytic conjunctival lesions. Graefes Arch Clin Exp Ophthalmol. 2010; 248: 111-115.

[42] Finger PT, Sedeek RW, Chin KJ. Topical interferon alfa in the treatment of conjunctival melanoma and primary acquired melanosis complex. Am J Ophthalmol. 2008; 145: 124-129.

[43] Kikuchi I, Kase S, Ishijima K, et al. Long-term follow-up of conjunctival melanoma treated with topical interferon alpha- $2 \mathrm{~b}$ eye drops as adjunctive therapy following surgical resection. Graefes Arch Clin Exp Ophthalmol. 2017; 255: 2271-2276.

[44] Krause L, Ritter C, Wachtlin J, et al. Recurrence rate following adjuvant strontium-90 brachytherapy after excision of conjunctival melanoma. [Rezidivhäufigkeit nach Exzision von Bindehautmelanomen und adjuvanter Strontium-90-Kontaktbestrahlung.] Klin Monatsbl Augenheilkd. 2008; 225: 649-652. [German]

[45] Karim R, Conway RM. Conservative resection and adjuvant plaque brachytherapy for early-stage conjunctival melanoma. Clin Exp Ophthalmol. 2011; 39: 293-298.

[46] Wuestemeyer H, Sauerwein W, Meller D, et al. Proton radiotherapy as an alternative to exenteration in the management of extended conjunctival melanoma. Graefes Arch Clin Exp Ophthalmol. 2006; 244: 438-446.

[47] Mor JM, Heindl LM. Systemic BRAF/MEK inhibitors as a potential treatment option in metastatic conjunctival melanoma. Ocul Oncol Pathol. 2017; 3: 133-141.

[48] Sagiv O, Thakar SD, Kandl TJ, et al. Immunotherapy with programmed cell death 1 inhibitors for 5 patients with conjunctival melanoma. JAMA Ophthalmol. 2018; 136: 1236-1241.

[49] Pinto Torres S, André T, Gouveia E, et al. Systemic treatment of metastatic conjunctival melanoma. Case Rep Oncol Med. 2017; 2017: 4623964.

[50] Dagi Glass LR, Lawrence DP, Jakobiec FA, et al. Conjunctival melanoma responsive to combined systemic BRAF/MEK inhibitors. Ophthalmic Plast Reconstr Surg. 2017; 33: el14-ell6.

(Tóth Gábor dr., Budapest, Mária u. 39., 1085 e-mail: gabortothgabor@gmail.com)

A cikk a Creative Commons Attribution 4.0 International License (https://creativecommons.org/licenses/by/4.0/) feltételei szerint publikált Open Access közlemény melynek szellemében a cikk bármilyen médiumban szabadon felhasználható, megosztható és újraközölhető, feltéve, hogy az eredeti szerző és a közlés helye, illetve a CC License linkje és az esetlegesen végrehajtott módositások feltüntetésre kerülnek. (SID_1) 